\title{
Optimizing Multimodal Literacy in Elementary School Learning
}

\author{
Ngatman, Ratna Hidayah, Tri Saptuti Susiani, Suhartono, Moh Salimi, Wahyu \\ Khasanah
}

Universitas Sebelas Maret

ngatman@staff.uns.ac.id

\section{Article History}

accepted 24/09/2019

\begin{abstract}
This article is a theoretical review for describing multimodal literacy in elementary school learning. The exposure in this article is based on the application of multimodal literation. This paper relates to the pedagogic aspect of the implementation of multimodal literacy learning in the view of constructivism. Learning aims to prepare students for the era of the 4.0 Industrial Revolution. The idea of Literation has now changed because at this time it relates to digital content. Thus, multimodal literacy needs to be examined to explain the role of multimodal literacy in elementary school learning.
\end{abstract}

Keywords: multimodal literacy, learning, elementary School

\section{Abstrak}

Artikel ini merupakan studi pustaka dalam rangka mengetahui sejauh mana optimalisasi penerapan literasi multimodal pada peserta didik dalam pembelajaran di sekolah dasar. Paparan di dalam artikel ini didasarkan pada penerapan literasi multimodal. Hal tersebut berkaitan dengan aspek pedagogik penerapan pembelajaran literasi multimodal dalam pandangan konstruktivisme. Pembelajaran diarahkan untuk mempersiapkan peserta didik dalam menghadapi era revolusi industri 4.0 yaitu era dimana kemajuan teknologi informasi dan komunikasi berkembang dengan pesatnya. Kemudian, gagasan literasi kini telah berubah karena pada era ini peserta didik hidup di lingkungan yang penuh dengan konten digital. Akhirnya, literasi multimodal perlu dikaji lebih lanjut untuk memperkuat sejauh mana optimalisasi penerapan literasi multimodal dalam pembelajaran di sekolah dasar.

Kata Kunci: literasi multimodal, pembelajaran, sekolah dasar

Social, Humanities, and Education Studies (SHEs): Conference Series https://jurnal.uns.ac.id/shes

p-ISSN 2620-9284

e-ISSN 2620-9292 


\section{PENDAHULUAN}

Generasi milenial saat ini, sebagai penduduk asli era digital, kita tidak hanya melek huruf dalam pengertian konvensional saja, melainkan juga melek huruf dengan cara yang inovatif yaitu cara yang melibatkan teks dengan gambar statis maupun dinamis, gerakan, audio, bahasa lisan serta bahasa tulisan. Selain itu, sama pentingnya juga bagi para pendidik di dunia digital saat ini yang harus perlu memiliki pengetahuan dan keterampilan baca tulis secara multimodal. Para pendidik harus dapat memahami dan menafsirkan teks multimodal, dan secara efektif mampu merancang dan mengkomunikasikan makna dari teks tersebut, dan akhirnya pendidik perlu mentransferkan pengetahuan dan keterampilan yang ia miliki kepada peserta didik mereka.

Sependapat dengan hal tersebut, dampak dari adanya era revolusi industri 4.0 pada bidang pendidikan saat ini bertujuan untuk mempersiapkan peserta didik yang mampu menguasai banyak kompetensi tidak hanya membaca dan menulis sebagai modal dasar pengetahuan mereka, melainkan literasi baru yang mampu meningkatkan keterampilan berpikir peserta didik menggunakan sumber-sumber pengetahuan baik dalam bentuk cetak, visual, digital, bahkan audio. Saat ini telah semakin banyak teknologi yang bermunculan untuk memfasilitasi peserta didik dalam mengembangkan ilmu pengetahuan mereka.

Menurut Undang-Undang Republik Indonesia Nomor 20 tahun 2003 tentang Sistem Pendidikan Nasional, Pembelajaran adalah proses interaksi peserta didik dengan pendidik dan sumber belajar pada suatu lingkungan belajar. Sependapat dengan hal tersebut, Darsono (2002: 24-25) mengemukakan bahwa pembelajaran adalah kegiatan yang dilakukan oleh guru sedemikian rupa sehingga tingkah laku siswa berubah ke arah yang lebih baik. Sedangkan menurut Sa'ud (2009: 124), pembelajaran merupakan serangkaian kegiatan yang dirancang untuk memungkinkan terjadinya proses belajar pada siswa.

Dari pendapat di atas, maka dapat disimpulkan bahwa pembelajaran merupakan suatu proses interaksi antara pendidik dan sumber belajar pada suatu lingkungan belajar yang dirancang untuk memungkinkan terjadinya proses belajar pada peserta didik sehingga terjadi perubahan ke arah yang lebih baik sesuai dengan tujuan yang akan dicapai.

Yang demikian itu harapannya melalui pembelajaran yang interaktif antara pendidik, peserta didik, dan sumber belajar akan membawa peserta didik ke arah yang lebih baik. Namun pada kenyataannya, pembelajaran di Indonesia masih berpegang pada paradigma lama, dimana peserta didik memperoleh ilmu dengan jalan diberikan atau diajarkan oleh orang yang dianggap lebih pandai, seperti layaknya pendidik yang memberikan ilmunya kepada peserta didik, pola pendidik yang aktif sedangkan peserta didik pasif, pendidik yang memberikan materi pelajaran sedangkan peserta didik hanya menerimanya, selanjutnya pendidik tahu sedangkan peserta didik tidak tahu, yang demikian itu masih terus dipraktekkan dalam pembelajaran di Indonesia (Munirah, 2015: 238).

Lebih lanjut lagi, menurut Yaumi (Wijayanti, dkk., 2015: 2) menyatakan bahwa karakteristik pembelajaran di sekolah dasar masih menggunakan model konvensional dan dalam pelaksanaan pembelajarannya masih didominasi oleh peran pendidik, sehingga pendekatan pembelajaran yang terpusat pada peserta didik belum terintegrasi secara penuh dalam pembelajaran di sekolah dasar. Hal itulah yang akhirnya berdampak pada proses pembelajaran yang kurang optimal. Terbukti dengan masih rendahnya kemampuan peserta didik dalam menggali pengetahuan secara mandiri dengan berliterasi.

Yang demikian itu merupakan salah satu inovasi pembelajaran. Hal itu dikarenakan literasi multimodal merupakan suatu ide gagasan dalam kegiatan pengembangan pembelajaran pada suatu lingkungan belajar yang dirasa sebagai hal 
baru dan dianggap lebih manjur untuk memungkinkan terjadinya proses belajar pada peserta didik sehingga terjadi perubahan ke arah yang lebih baik sesuai dengan tujuan yang akan dicapai.

Berdasarkan kebijakan pemerintah melalui Peraturan Menteri Pendidikan dan Kebudayaan Nomor 23 Tahun 2015, Menteri Pendidikan dan Kebudayaan Republik Indonesia telah menetapkan program Gerakan Literasi Pendidikan. Program ini dilatarbelakangi oleh faktor rendahnya keterampilan literasi pada pembelajaran di tingkat sekolah khususnya di sekolah dasar yang merupakan lembaga perintis budaya literasi anak. Hal tersebut terbukti dengan belum adanya pengembangan kompetensi dan minat peserta didik pada saat pembelajaran.

Selain itu, seiring perkembangan zaman saat ini teknologi telah banyak bermunculan yang mampu memfasilitasi peserta didik dalam membiasakan kemampuan literasi mereka secara multimodal. Pengertian secara umum dari literasi multimodal adalah berbagai cara dalam memahami pengetahuan seperti bahasa, gerakan, dan gambar dengan menggunakan berbagai modalitas seperti aural, visual, gestural, spasial, dan linguistik yang terintegrasi untuk membangun suatu makna.

Istilah 'literasi multimodal' pertama kali diusulkan oleh Jewitt \& Kress untuk menggambarkan bagaimana makna dibuat, didistribusikan, diterima, ditafsirkan, dan dibuat ulang melalui beragam model representasi secara terpadu (Norishah, dkk: 2013). Penggunaan literasi multimodal dalam pembelajaran sangat beralasan sebagai upaya dalam mengembangkan kompetensi para peserta didik. Karenanya literasi multimodal, didefinisikan sebagai sebuah kerangka kerja yang membutuhkan interpretasi secara kolektif dari dua atau lebih teks, visual, video, grafik, animasi, suara, musik, gerakan dan ekspresi wajah untuk menghasilkan suatu makna yang nantinya akan memudahkan peserta didik dalam memahami suatu pengetahuan (Kress, 2010: 54).

Semua bentuk multimodal ini mampu memungkinkan peserta didik untuk memperoleh informasi dengan berbagai cara dalam pembelajaran atau tujuan lainnya. Teks dalam bentuk cetak saja masih sulit dalam memenuhi kebutuhan dan minat peserta didik dalam dunia digital dan belum optimalnya literasi multimodal sering dikutip dalam dunia pendidikan (Gee, 2004).

Oleh karena itu, sangat direkomendasikan bagi para pendidik untuk mengadakan pendekatan yang lebih konstruktif dengan mengambil manfaat dari adanya berbagai teknologi baru yang ada supaya mampu berperan secara optimal dalam penerapan literasi multimodal pada pembelajaran di sekolah dasar dengan tujuan meningkatkan kemampuan peserta didik dalam menghadapi era revolusi industri 4.0.

\section{PEMBAHASAN}

Para pendidik membutuhkan kesempatan untuk memanfaatkan literasi multimodal dalam kehidupan mereka sendiri sebelum mengintegrasikannya secara efektif dengan praktik pengajaran mereka (Lankshear \& Knobel, 2003). Untuk tujuan ini, program pelatihan pendidik harus melibatkan pengetahuan dan keterampilan untuk mengintegrasikan literasi multimodal ke dalam praktik mereka. Peserta didik juga perlu diajari bagaimana peserta didik mampu menyulap berbagai model untuk menentukan cara yang paling tepat dan bagaimana makna dalam teks multimodal diatur melalui pemilihan dan penggunaan model yang berbeda dalam berbagai kombinasi (Jewitt, 2009: 15).

Terlebih lagi, penggunaan teks multimodal memungkinkan peserta didik untuk memanfaatkan literasi di luar sekolah dan membantu mereka menjadi lebih cakap dalam berliterasi (Sewell \& Denton, 2011: 61). Teks multimodal tidak selalu berarti penggunaan teknologi, dan teks multimodal dapat berbasis kertas, langsung, atau digital. Teks multimodal berbasis kertas meliputi buku gambar, buku teks, novel grafis, komik, dan poster. Teks multimodal langsung, misalnya, tari, pertunjukan, dan 
dongeng lisan, menyampaikan makna melalui kombinasi berbagai model seperti bahasa tubuh, spasial, audio, dan lisan. Teks multimodal digital termasuk film, animasi, peragaan slide, e-poster, cerita digital, serta podcast. Komunikasi kontemporer yang efektif menuntut peserta didik untuk dapat memahami, merespons, dan menyusun makna melalui teks multimodal dalam beragam bentuk (State Government of Victoria Australia, 2019).

Dalam teks visual, misalnya representasi orang, objek, dan tempat dapat disampaikan menggunakan pilihan sumber semiotik visual seperti garis, bentuk, ukuran, dan simbol, sedangkan bahasa tertulis akan menyampaikan makna ini melalui kalimat menggunakan kelompok kata benda dan kata sifat ditulis atau diketik di atas kertas atau diketik di layar (Callow, 2013).

Dalam strategi pelaksanaan optimalisasi penerapan literasi multimodal pada pembelajaran bertujuan untuk memberikan kesempatan kepada peserta didik untuk berpikir kreatif. Selanjutnya peserta didik mampu melakukan berbagai aktifitas di dalam pembelajaran dengan mengeksplorasi kemampuannya dan dapat menemukan pengetahuannya dengan sendiri.

Strategi pembelajaran penerapan literasi multimodal merujuk kepada asumsi bahwa setiap peserta didik mulai dari sejak usia anak-anak sampai dengan menginjak jenjang Pendidikan Tinggi telah memiliki gagasan atau pengetahuan mengenai peristiwa-peristiwa yang terjadi di lingkungan sekitarnya. Strategi pembelajaran yang demikian akan memungkinkan tersedianya kesempatan yang lebih banyak untuk melibatkan peserta didik di dalam kelas secara aktif, kemudian melakukan eksplorasi, serta menggali secara lebih mendalam potensi atau kemampuan peserta didik baik secara aspek kognitif, afektif maupun psikomotoriknya.

Dalam strategi pembelajaran penerapan literasi multimodal peserta didik tidak didoktrinasi pengetahuan saja, melainkan mereka menemukan dengan sendirinya dan mengeksplorasi pengetahuan tersebut dengan apa yang telah mereka ketahui dan pelajari sendiri. Sosok pendidik dalam pembelajaran ini berperan sebagai fasilitator bagi peserta didik dalam menggali pengetahuannya melalui literasi multimodal.

Fokus dalam pembelajaran literasi multimodal bukan hanya sebatas kemampuan untuk membaca dan menulis teks-teks linier, melainkan adanya kebutuhan yang lebih meningkat bagi peserta didik. Pada era ini, peserta didik membutuhkan kemampuan untuk memahami berbagai pengetahuan yang disajikan melalui berbagai teks yang terkait dengan beragam bentuk multimodal, seperti halnya dalam bentuk tulisan, video, audio, gambar visual, dan elemen-elemen berbau konten digital.

Sependapat dengan hal tersebut, Ryu \& Boggs (2016) menyatakan bahwa target dari pembelajaran penerapan literasi multimodal tidak hanya terbatas juga pada komunikasi berdasarkan teks cetak tradisional melainkan teks multimedia dan teks multimodal. Melalui teks multimedia dan teks multimodal di dalamnya akan mencakup elemen-elemen visual, audio, dan teknologi untuk menciptakan makna. Sehingga tujuan dari pembelajaran literasi multimodal adalah untuk meningkatkan kapabilitas abad 21 (era revolusi industri 4.0).

Lebih lanjut lagi, menurut Black and Plowright dan Priyatni (Firmansyah, 2018) menyatakan bahwa target dari pembelajaran literasi multimodal, yaitu: pembelajaran literasi multimodal bersumber dari pengalaman belajar baik formal maupun informal yang dapat digunakan untuk mengembangkan pengetahuan dan aktivitas peserta didik. Selanjutnya menurut Walsh (2009), pandangan pendidikan literasi multimodal harus diterapkan dalam menganalisis berbagai jenis konten digital yang diakses para peserta didik karena dalam hal tersebut akan melibatkan proses literasi di luar membaca dan menulis.

Manfaat pembelajaran literasi multimodal, yakni: pertama, pembelajaran lebih efisien karena peserta didik dikenalkan dengan teks multimodal (visual, audio, dan teknologi) sehingga pembelajaran lebih mengarah pada pemanfaatan teks secara 
menyeluruh. Kedua, dapat meningkatkan kapabilitas peserta didik yang memiliki preferensi ganda karena pembelajaran literasi multimodal merupakan kombinasi antara visual, audio dan gerak. Ketiga, strategi pembelajaran literasi multimodal termasuk strategi pembelajaran untuk belajar lebih cepat dan pada tingkat yang lebih tinggi dalam mengingat di kemudian hari. Keempat, strategi pembelajaran literasi multimodal dapat meningkatkan perhatian para peserta didik dalam pembelajaran. Kelima, membiasakan peserta didik dengan berbagai gaya belajar sehingga peningkatan kemampuan lebih efektif (Firmansyah: 2018).

Secara umum, studi pustaka ini diharapkan dapat memberikan gambaran bagaimana pemanfaatan teks multimodal bermuatan kearifan lokal dapat meningkatkan kompetensi literasi multimodal peserta didik di Era Revolusi Industri 4.0 yang tengah menjadi perbincangan hangat oleh sejumlah akademisi dan praktisi baik di tingkat nasional maupun tingkat global. Pemahaman yang utuh mengenai kompetensi literasi multimodal diharapkan dapat membantu pengajar di Indonesia untuk merumuskan pembelajaran yang sesuai dengan kebutuhan global.

Berdasarkan uraian di atas dapat disimpulkan bahwa optimalisasi penerapan literasi multimodal dalam pembelajaran di sekolah dasar merupakan program yang baik bagi peserta didik di era ini. Era dimana kemampuan berliterasi secara multimodal merupakan prioritas utama yang perlu diterapkan.

\section{SIMPULAN}

Para pendidik memiliki kesempatan untuk menciptakan lingkungan belajar yang kaya bagi peserta didik mereka, yang ditingkatkan oleh informasi dan sumber daya yang sangat besar di Internet dengan menggunakan berbagai model. Pendidik membutuhkan dukungan untuk belajar dan dapat menggunakan jenis baru pembelajaran literasi multimodal agar siap untuk mengajar peserta didik di ruang kelas abad ke-21. Berdasarkan kajian ini, satu saran penting bagi pembelajaran di Indonesia yaitu perlunya optimalisasi penerapan literasi multimodal dalam pembelajaran di sekolah dasar untuk menghadapi era revolusi industri 4.0. Dengan demikian, peserta didik nantinya akan memiliki wawasan yang luas dalam menggali pengetahuanya denga sendiri.

\section{DAFTAR PUSTAKA}

Callow, J. (2013). The Shape of Text to Come: How Image and Text Work. Sydney: Primary English Teaching Association of Australia.

Darsono. (2002). Teori Pembelajaran. Jakarta: Erlangga.

Departemen Pendidikan Nasional. (2003). Undang-Undang Republik Indonesia No 20 Tahun 2003 tentang Sistem Pendidikan Nasional. Jakarta: Depdiknas.

Departemen Pendidikan dan Kebudayaan. (2015). Peraturan Menteri Pendidikan dan Kebudayaan Nomor 23 Tahun 2015 tentang Gerakan Literasi Pendidikan. Jakarta: Depdikbud.

Firmansyah, M. B. (2018). Model Pembelajaran Diskusi Berbasis Perilaku Berliterasi Untuk Keterampilan Berbicara.

Firmansyah, M. B. (2018). Kompetensi Literasi multimodal peserta didik: Studi Pustaka Terhadap Teks multimodal Bermuatan Kearifan Lokal Serta Implementasinya Dalam Pembelajaran.

Jewitt, C. (ed.) (2009) The Routledge Handbook of Multimodal Analysis, London: Routledge.

Jewitt, C., \& Kress, G. R. (Eds.). (2003). Multimodal literacy. New York: Lang.

Kress, G. (2010). Multimodality: a social semiotic approach to contemporary communication. London: Routledge.

Lankshear, C. \& Knobel, M. (2003). New Literacies: Changing knowledge and classroom learning. Buckingham and Philadelphia: Open University Press. 
Munirah. (2015). Sistem Pendidikan di Indonesia. Auladuna. 2(2), 233-245.

Nasir, M. (2018). Pendidikan Tinggi Berkualitas:"Mendorong Kemajuan IPTEK, Inovasi, dan Daya Saing Bangsa di Era Revolusi Industri 4.0".

Norishah, dkk. (2013). The multimodal Literacy Practices of Malaysian Youths in a Digital Environment. Procedia - Social and Behavioral Sciences.

Ryu, J., \& Boggs, G. 2016. Teachers' Perceptions about Teaching Multimodal Composition: The Case Study of Korean English Teachers at Secondary Schools. English Language Teaching, 9(6), 52.

Sa'ud, U. S. (2015). Inovasi Pendidikan. Bandung: Alfabeta.

Sewell, W.C. \& Denton, S. (2011). Multimodal Literacies in the Secondary English Classroom. English Journal, 100 (5), 61-65.

State Government of Victoria Australia (2019). Multimodal literacy. Diunduh dari: https://www.education.vic.gov.au/school/teachers/teachingresources/discipline/en glish/literacy/multimodal/Pages/default.aspx\#top pada tanggal 8 September 2019.

Walsh, M. (2010). multimodal literacy: What does it mean for classroom practice?. Australian Journal of Language and Literacy. 33(3): 211-239.

Wijayanti, D. A. I, dkk. (2015). Analisis kemampuan Berpikir Kritis peserta didik Kelas V dalam Pembelajaran IPA di 3 SD Gugus X Kecamatan Buleleng. E-Journal PGSD Universitas Pendidikan Ganesha Jurusan PGSD, 3(1), 1-12. 